\title{
Gereja Sebagai Umat Allah dan Rekan Negara
}

\section{The Church as God's People and The Patner of State}

\author{
Herry Susantol $)^{*}$ \\ 1) Prodi Teologi Sekolah Tinggi Alkitab Tiranus Bandung \\ *Penulis korespondensi: herrysusanto@protonmail.com
}

Received: 21 July 2018/Revised: 07 November 2018 /Accepted: 12 December 2018

\begin{abstract}
Abstrak
Tulisan ini menguraikan posisi gereja sebagai umat Allah dan warga negara berdasarkan tinjauan Injil Lukas, dan Kisah Para Rasul. Kemudian melihat relevansinya bagi gereja di Indonesia, untuk mencari pendirian yang tepat terkait sikap umat Kristen terhadap negara. Dengan menggunakan pendekatan analisis naratif yang dipadukan dengan analisis sosial oleh Philip F. Esler. Tulisan ini akan meninjau interaksi Paulus dengan petinggi-petinggi Romawi. Berdasarkan asumsi kesatuan teks yang merupakan karakteristik analisis naratif, pembahasan tentang interaksi tersebut akan dihubungkan dengan dimensi sosial dalam keseluruhan tulisan Lukas. Hasil analisis teks dijelaskan bahwa gereja bukanlah oposisi bagi negara, melainkan rekan yang memiliki tanggung jawab sosial untuk mengaktualkan shalom bagi warga gereja, dan masyarakat yang lebih luas.
\end{abstract}

Kata-kata kunci: gereja, negara, tanggung jawab sosial, diakonia, analisis naratif

\section{Abstract}

This article aims to elaborate church position as God's people and citizens of a nation based on observations from Gospel of Luke and the Book of Acts. Afterward, it will examine its relevance for the church in Indonesia, to find the right position regarding the Christian attitude toward the nation. By utilizing a narrative analysis approach, combined with social analyses conducted by Philip F. Esler, this writing will observe the interaction between Paul and Roman officials. In accordance with the assumption of textual unity (which is characteristic of narrative analysis), the study on the interaction will be connected with the social dimension of all Luke's writing. Based on the result of the biblical text analysis, it is concluded that the church is not the opposition of the nation, rather a partner that has social responsibility to actualize shalom for church community, and a wider scope of society. Accordingly, the church in Indonesia should strengthen diaconal ministry.

Keywords: church, nation, social responsibility, diaconal, narrative analysis 


\section{Pendahuluan}

Dalam melihat identitas sebagai umat Allah, dan juga bagian dari sebuah negara, gereja cenderung dualistik. Ini memengaruhi seberapa besar kontribusi yang bisa diberikan gereja kepada negara. Perceraian antara apa yang disebut "rohani", dan "sekuler" cukup menghambat warga gereja untuk menemukan perannya dalam mengaktualkan kepedulian terhadap negara. ${ }^{1}$ Gereja cenderung menjadi wilayah privat, dan menjauhkan diri dari dimensi sosial yang lebih luas. Isu-isu kemasyarakatan tidak dilihat sebagai ranah kerja gereja karena dianggap tidak berkaitan dengan kebutuhan spiritual manusia.

Tentu misi Kristen juga akan menjadi sempit. Dalam tulisannya, Sebastian Kim menggumuli perpaduan antara missiologi dan teologi publik. Tujuannya adalah membangun sebuah pemikiran misi yang mampu berinteraksi dengan kebutuhan publik yang lebih luas dengan alasan bahwa dunia diciptakan, dikuasai bahkan ditebus oleh Allah. ${ }^{2}$ Misi yang bersentuhan dengan kebutuhan sosial demikianlah yang menjadi karakteristik pelayanan jemaat perdana yang dikisahkan dalam Kisah Para Rasul.

Tulisan ini didesain untuk menelusuri pesan Lukas melalui kitab Kisah Para Rasul untuk melihat bagaimana warga gereja seharusnya menempatkan diri dalam konteks sosial mereka. Umumnya ahli Perjanjian Baru sepakat bahwa Kisah Para Rasul dan Injil Lukas adalah dua tulisan yang berhubungan. Kitab sejarah perkembangan jemaat mula-mula ini dilihat sebagai kelanjutan dari pelayanan Yesus Kristus oleh para murid atau pengikut-Nya. Misi Yesus berdasarkan Injil Lukas kental dengan dimensi sosial, yang kemudian dilanjutkan oleh para murid sebagaimana dilaporkan dalam Kisah Para Rasul. Dalam Kisah Para Rasul, warna sosial ini penting dalam mendasari sikap gereja

'Dualisme antara hal "rohani" dan "sekuler", secara implisit terlihat pada pandangan Ronald Helweldery: "Gereja cenderung memperlakukan dirinya sebagai tubuh ilahi (yang rohani) yang tak boleh tercemari hal-hal duniawi [yang sekuler]. Gereja memahami dirinya sebagai institusi yang harus steril dari anasir-anasir politik" Tulisan "Gereja dalam Konteks Relasi Negara dan Masyarakat (Sebuah Upaya Memahami Reposisi Peran Politis Gereja)," Waskita: Jurnal Studi Agama dan Masyarakat 2, no. 2 (2014): 124. Di samping itu ada gagasan kesalehan personal—sebuah sikap yang dihindari oleh kelompok Kristen transformatif-yang "menekankan kesalehan pribadi dan anti terhadap politik. Kustini, dan Syaiful Arif, "Kekristenan, dan Nasionalisme di Kota Bogor" Harmoni: Jurnal Multikultural e Multireligius 15, no. 2 (2016): 101. Tentu saja hal ini memunculkan kegamangan dalam memposisikan gereja di dalam masyarakat secara praksis. Dampaknya adalah minimnya kontribusi gereja dalam mengatasi isu-isu sosial atau kemasyarakatan, karena tidak dipandang sebagai ranah spiritual.

${ }^{2}$ Sebastian C. H. Kim, "Mission's Public Engagement: The Conversation of Missiology and Public Theology," Missiology 45, no. 1 (2017): 21. 
terhadap negara, yang terefleksikan dari interaksi Paulus dengan pemimpin-pemimpin Romawi. Maka, berdasarkan interaksi tersebut, tulisan ini akan mencoba menarik prinsip penting berkenaan dengan bagaimana gereja menempatkan dirinya sebagai umat Allah sekaligus sebagai bagian dari negara?

Temuan dari tulisan ini adalah Kekristenan dalam Kisah Para Rasul tidak diposisikan sebagai musuh negara. Lebih jauh lagi, tulisan ini melihat bahwa dengan adanya dimensi sosial dalam misi gereja perdana, yang dipadukan dengan tidak adanya permusuhan antara Kekristenan dan negara, maka gereja adalah rekan bagi negara dalam mewujudkan kesejahteraan masyarakat. Ini adalah panggilan gereja untuk menghadirkan shalom bagi Indonesia.

\section{Metode}

Dengan menggunakan prinsip analisis yang umumnya diterapkan dalam analisis naratif, tulisan ini mencoba menggali dan menguraikan isi dari Kisah Para Rasul untuk menjelaskan prinsip teologis yang terkandung di dalam cerita yang dilaporkan. Kemudian, untuk mengkaji pemikiran-pemikiran sosial-politik yang termuat dalam kitab ini, penelitian yang dilakukan oleh Philip F. Esler ${ }^{3}$ akan digunakan untuk menelaah interaksi dengan pemimpin-pemimpin Romawi.

Analisis naratif bisa dikatakan sebagai respons terhadap hegemoni analisis historis terhadap teks-teks Alkitab. Berbeda dengan analisis historis yang fokus pada rekonstruksi latar belakang sejarah teks, dengan menggunakan banyak bahan-bahan eksternal, analisis naratif lebih berorientasi pada elemen-elemen literer internal. Dalam studi terhadap kitab-kitab Injil, karya dari Rhoads, dan Michie, Mark as Story, telah memperkenalkan pendekatan analisis naratif dalam membaca InjilInjil kanonik.

Analisis dari tulisan ini akan melengkapi apa yang dibahas oleh Esler. Dalam tinjuannya, Esler cenderung mengandalkan analisis sosiohistoris. Penelitian ini bertujuan untuk menjadi penyeimbang bagi bahasan-bahasan serupa yang sepenuhnya menerapkan pendekatan sosio-historis. Jadi sekalipun unsur sosial teks menjadi perhatian dalam pengamatan makala ini $^{4}$, namun itu dilakukan dalam konteks membaca teks sebagai tulisan naratif, sehingga genre tulisan tidak terabaikan.

${ }^{3}$ Philip Francis Esler, Community and Gospel in Luke-Acts: The Social and Political Motivations of Lucan Theology (Cambridge: Cambridge University, 1989).

${ }^{4}$ Sekalipun analisis naratif tidak bergantung sepenuhnya pada elemen-elemen historis dari teks, bukan berarti dimensi sosial yang melatarbelakangi teks kemudian diabaikan. Ketika teks merefleksikan unsur-unsur budaya, sosial bahkan politik 
Berkaitan dengan data-data yang akan dianalisis bersumber dari teks Kisah Para Rasul yang menuturkan interaksi Paulus dengan petinggi-petinggi Romawi. Sorotan akan diberikan kepada pernyataan atau pandangan para petinggi tersebut terhadap Paulus, yang digali dengan berdasarkan suasana konteks logika teks.

Apa saja karakteristik dari sebuah naratif yang dapat menolong dalam upaya menemukan makna dari teks-teks yang akan dilihat dalam tulisan ini? Berbicara tentang elemen-elemen dari sebuah naratif, tentu ada beberapa yang bisa disebutkan. Namun, tulisan ini, dalam membaca teks, akan fokus pada kesatuan cerita. ${ }^{5}$ Dalam kritik naratif, bagianbagian yang berbeda dari sebuah cerita dipandang sebagai satu kesatuan dengan fungsi literernya masing-masing, sehingga dalam membangun ide, penafsir harus mempertimbangkan gagasan-gagasan dari bagianbagian yang berbeda.

Oleh sebab itu, dalam melihat teks-teks yang melaporkan interaksi Paulus dengan pemimpin-pemimpin Romawi, tulisan ini juga akan mencoba melihat keterkaitan dengan bagian lain dari Kisah Para Rasul. Bahkan, karena tulisan ini menerima kesatuan antara Injil Lukas dan Kisah Para Rasul, maka akan dilihat unsur-unsur yang sebelumnya sudah dimunculkan melalui pelayanan Yesus Kristus yang dilaporkan dalam Injil Lukas tersebut.

Dalam proses pengkajiannya, tulisan ini akan fokus pada tiga aspek, pertama, dengan dasar keyakinan bahwa misi gereja mula-mula yang dilaporkan dalam Kisah Para Rasul adalah kelanjutan dari karya Yesus dalam Injil Lukas, penting untuk melihat dimensi sosial yang ada dalam Injil tersebut yang dilanjutkan oleh pelayanan gereja perdana. Kedua, fokus akan terarah pada nilai yang tersirat dalam interaksi antara Paulus dengan pemimpin-pemimpin Romawi. Lukas, guna menemukan relevansi dari analisis teks dengan konteks Indonesia, tulisan ini akan menggumuli temuan eksegesa di dalam konteks Indonesia.

\footnotetext{
tertentu, analisis naratif tidak boleh mengabaikannya, selama itu adalah bagian internal dari teks itu sendiri. Sebagai contoh, teks-teks Injil kanonik secara jelas menunjukkan bahwa mereka dituliskan kepada komunitas yang menggunakan bahasa Yunanipaling tidak bahasa Yunani adalah salah satu bahasa yang digunakan — sehingga unsurunsur sosial dan gramatikal terkait, harus dapat ditelusuri dengan baik, tentu dengan menjaga batasan-batasan yang tidak membuat penafsir terlalu jauh dalam mengumpulkan data-datanya.

${ }^{5}$ Inilah yang membedakan kritik historis dengan kritik naratif. Seperti disampaikan oleh James L. Resseguie bahwa kritik naratif adalah peralihan dari kritik historis yang cenderung melihat bagian-bagian teks terisolasi satu dengan yang lainnya, sedangkan analisis naratif memahami teks secara keseluruhan adalah satu kesatuan dalam buku Narrative Criticism of the New Testament: An Introduction (Grand Rapids: Baker Academic, 2015), 19).
} 


\section{Pembahasan}

\section{Dimensi Sosial dan Pelayanan Gereja}

Sebelum mendalami bagaimana dimensi sosial pelayanan Yesus dalam Injil Lukas berkelanjutan dalam pelayanan para suksesor-Nya, penting terlebih dahulu melihat kesatuan antara kedua kitab. Ada konsensus di antara banyak ahli Perjanjian Baru terkait dengan kesatuan antara Injil Lukas dan Kisah Para Rasul. ${ }^{6}$ Cadbury menjelaskan bahwa pendahuluan dari kedua kitab yang memiliki banyak kesamaan, merupakan indikator kesatuan antara kedua kitab ini. ${ }^{7}$ Temuan dari Robert C. Tannehill lebih bersifat mendalam dengan menelusuri keseragaman perspektif teologis. ${ }^{8}$ Dalam penjelasannya, Tannehill menguraikan bahwa tujuan Allah adalah pengikat kedua kitab. Ini terlihat dalam apa yang Tannehill katakan: "Luke-Acts has a unified plot because there is a unifying purpose of God behind the events which are narrated, and the mission of Jesus and his witnesses represents that purpose of God being carried out through human action." ${ }^{\prime 9}$ Karya yang terkini adalah tulisan dari Ben Harris yang melihat kesatuan kedua kitab berdasarkan kesamaan teknik dan struktur pendahuluan tulisan dan alat retorik:

Luke introduced his work as a whole with a general prologue (Luke 1:1-4), which is made up of four balanced clauses. Looking for this approach to content and structure at the beginning of the second part of the work, I proposed that the same technique was employed there also (Acts 1:1-3). And following a well-known literary model that Luke might reasonably be supposed to have encountered during his formative years as well as the probable methods of recitation in the first-century Graeco-Roman world he inhabited, I suggested that the same rhetorical device is used at the two midway points in the work (Luke 12:1-3 and Acts 14:24-28)..$^{10}$

Dengan merujuk kepada tokoh-tokoh ini, maka kesatuan antara Injil Lukas dan Kisah Para Rasul dapat diterima oleh beberapa ahli

${ }^{6} \mathrm{~S}$. John Roth, The Blind, the Lame, and the Poor: Character Types in Luke-Acts (Sheffield, England: Sheffield Academic Press, 1997), 12-18.

${ }^{7}$ Henry J. Cadbury, The Making of Luke-Acts (Peabody: Hendrickson Publishers, 1999), 8; lihat juga Joel B. Green, "Luke, Gospel Of," in Dictionary of Jesus and the Gospels, ed. Joel B Green, Second Edition. (Downers Grove: IVP Academic, 2013), 541.

${ }^{8}$ Tannehill, The Narrative Unity, 1:xiii.

${ }^{9}$ Ibid., 1:2 (diskusi lengkap dapat dilihat pada karya Tannehill, halaman 1-12).

${ }^{10}$ Ben Harris, "l Gospel, 4 Acts: Introduction (s) to the Genuis of Luke," Evangelical Quarterly 89, no. 1 (January 2018): 3-20. 
penting dalam studi biblika. ${ }^{11}$ Terkait dengan kesatuan tersebut, maka Kisah Para Rasul tidak dapat dibaca terpisah dari Injil Lukas. Termasuk ketika akan mendalami motif politik yang termuat dalam salah satu kitab tersebut. ${ }^{12}$

Di antara Injil Sinoptik lainnya, Injil Lukas lebih menekankan dimensi sosial pelayanan Yesus Kristus. Aspek sosial pelayanan Yesus tersebar di banyak segmen naratif Injil Lukas ini. Namun yang terpenting, karena berfungsi sebagai gambaran bagi pelayanan Yesus di seluruh Injil Lukas, Lukas 4:16-30 adalah bagian esensial tentang Yesus dan kepedulian sosial. Dalam keseluruhan konteks Injil Lukas, bagian ini menghubungkan misi yang dilakukan oleh Yesus dengan kepedulian sosial. Pernyataan dalam Lukas 4:18 memberi kesan bahwa Yesus memperoleh kuasa untuk memberitakan Kabar Baik kepada orang-orang marginal karena Roh Allah yang ada pada-Nya. Sedangkan para murid, sebelum memulai pelayanan, mereka menerima Roh Kudus (Kis. 2:1-13) sebagai penggenapan dari janji kuasa dalam Kis. l:8. Hal yang menarik adalah pelayanan keduanya dikaitkan dengan unsur kepedulian sosial. Yesus menjadi pembawa Kabar Baik bagi mereka yang secara sosial terdiskriminasi (Luk. 4:18-19) dan jemaat perdana, dalam pelayanan mereka, memberikan sebagian milik mereka untuk memberi bantuan kepada mereka yang miskin (Kis. 2:44-45; 4:32-37).

Terkait dengan dimensi sosial dalam Kisah Para Rasul, karya Blomberg melihat signifikansi dari aksi sosial jemaat perdana yang tercatat dalam kitab tersebut. Berdasarkan kesatuan Injil Lukas dan Kisah Para Rasul, dapat terlihat implementasi elemen sosial dari Injil Lukas dalam pelayanan para murid. Sekalipun dalam Kisah Para Rasul, secara eksplisit, aksi sosial hanya terlihat jelas dalam pasal 2:44-45 dan 4:32-37, namun bukan berarti kepedulian sosial tidak menjadi unsur penting dalam pelayanan para murid. Secara gramatikal, aksi sosial dalam kedua nas tidak bisa dipahami sebagai tindakan once-for-all, karena menggunakan kata kerja imperfek. ${ }^{13}$ Keseriusan pelayanan Kristen terhadap dukungan sosial kepada mereka yang termarginalkan dapat

${ }^{11}$ Keyakinan akan kesatuan antara Injil Lukas dan Kisah Para Rasul juga dapat dilihat dalam karya-karya penting lainnya seperti Darrell L. Bock, A Theology of Luke-Acts: God's Promised Program, Realized for All Nations, Biblical Theology of the New Testament (Grand Rapids: Zondervan, 2012); I. Howard Marshall, "Acts and the 'Former Treaties," in The Book of Acts in Its First Century Setting, ed. Bruce W. Winter and Andrew D. Clark, vol. 1 (Grand Rapids: Eerdmans, 1993), 163-182.

${ }^{12}$ Robert F O'Toole, "Luke's Position on Politics and Society in Luke-Acts," in Political Issues in Luke-Acts, ed. Richard J. Cassidy and Philip J. Scharper (Eugene, OR: Wipf and Stock Publishers, 2015), 3.

${ }^{13}$ Craig L. Blomberg, Neither Poverty Nor Riches: A Biblical Theology of Material Possession (Grand Rapids: Eerdmans, 1999), 162, 165. 
terlihat dalam kisah Ananias dan Safira (5:1-11) dan pemilihan para pelayan meja untuk mengatasi kesenjangan dalam dukungan finansial terhadap janda-janda berlatar belakang budaya Yunani (6:1-7).

Dimensi sosial ini memberi kesan bahwa pelayanan Kristen tidaklah bersifat dualistik. Restorasi yang dibawa oleh misi Kristen tidak hanya menyentuh aspek roh mereka yang dilayani, namun juga menyentuh kebutuhan sosial mereka. Berangkat dari gagasan ini, ketika pembaca bertemu dengan bagian yang melaporkan percakapan antara Paulus dengan pemimpin-pemimpin Romawi, aspek sosial, atau lebih tepatnya, aspek sosial-politik, dapat dimunculkan berkenaan dengan sikap Kekristenan terhadap negara.

Tanggung jawab sosial Kristen yang termuat dalam pelayanan para murid dalam Kisah Para Rasul mengizinkan pembaca untuk membawa sikap teologis gereja ke arah yang lebih luas, tidak hanya hubungan antar gereja dan Allah, melainkan juga menyentuh hubungan antara gereja dan masyarakat. Karya misi gereja harus dipandang lebih luas, sebagaimana dituliskan oleh Emiola Nihinlola, "... the scope of the mission/task of the church in the world needs to be enlarged, to include social ministry and action in support of the oppressed, marginalized and impoverished people in the world." ${ }^{14}$

\section{Interaksi Paulus Dengan Pejabat-Pejabat Romawi}

Secara eksplisit Kisah Para Rasul tidak memperlihatkan motif politik. Namun bila dicermati, khususnya pada bagian-bagian yang melaporkan interaksi para rasul dengan para petinggi Romawi, ada bagian-bagian yang menunjukkan sikap Kekristenan perdana terhadap kekaisaran Romawi.

Menurut Esler, secara teologis, Lukas memiliki sensitivitas politik, yang tercerminkan melalui kemunculan setting yudisial Romawi dalam Kisah Para Rasul, khususnya terkait dengan keberadaan Paulus. ${ }^{15}$ Secara jelas Esler mengatakan,

\footnotetext{
${ }^{14}$ Emiola Nihinlola, "The Church as a Civil Society: An African Ecclesiology," Evangelical Review of Theology 41, no. 1 (January 2017): 56.

${ }^{15}$ Esler, Community and Gospel in Luke-Acts, 201. Hal yang sama dapat dilihat dalam karya dari Richard Cassidy (Jesus, Politics, and Society: A Study of Luke's Gospel [Oregon: Wipf and Stock Publisher, 2015]). Sekalipun lebih fokus pada Injil Lukas, namun Cassidy juga menunjukkan hadirnya motif politik dalam Kisah Para Rasul. Misalnya pada saat mengemukakan keberadaan Lukas sebagai sejarawan, tulisan tersebut menunjukkan bahwa naratif-naratif yudisial dalam Kisah Para Rasul mencerminkan isu sosio-politik-hal ini menujukkan bahwa Lukas memiliki kepekaan terhadap situasi konteks pada saat itu-dalam masyarakat Yunani-Romawi (hal. 15). Ahli lain yang menunjukkan adanya motif politik dalam tulisan Lukas adalah artikel oleh Loveday Alexander, "Luke's Political Vision" Interpretation 66, no. 3 (2012): 283-293. Selaras
} 
"... the birth of Jesus in Bethlehem occurs as a direct result of Joseph's unquestioning obedience to an imperial decree must have seemed a revealing example of the possibility that Roman politics were not necessarily inconsistent with the divine purpose."16

Sensitivitas politik ini juga terlihat dalam Kisah Para Rasul, khususnya ketika Paulus berinteraksi dengan pejabat-pejabat Romawi dalam konteks pengadilan. Hal yang mengemuka dari interaksi tersebut adalah gereja bukanlah musuh kekaisaran. Sebagaimana akan ditunjukkan oleh tinjauan di bawah, sekalipun Paulus mengalami penahanan, alasannya bukan karena dia melanggar hukum negara, melainkan mencegah kekacauan yang bisa ditimbulkan oleh orang-orang Yahudi.

\section{Paulus di Tesalonika dan Korintus (Kis. 17:1-9; 18:11-17)}

Sikap positif Kekristenan terhadap negara dapat terlihat dari respons aparat negara terhadap aktivitas kristiani yang dianggap negatif oleh sebagian anggota masyarakat. Hal ini yang terlihat dalam pengalaman Paulus ketika berada di Tesalonika (Kis. 17:1-9). ${ }^{17}$ Setelah berbicara tiga hari Sabat berturut-turut di sinagoge tentang Yesus sebagai Mesias, sejumlah orang Yahudi dan Yunani berkeputusan untuk menjadi pengikut Yesus (Kis. 17:1-4).

Adanya mereka yang beralih keyakinan ini kemudian menimbulkan keresahan di kalangan komunitas Yahudi di kota tersebut (Kis. 17:5-7). Reaksi dari orang-orang Yahudi ini menimbulkan kekacauan. Tudingan yang diberikan kepada Paulus berindikasi adanya upaya menempatkan dia sebagai musuh kekaisaran Romawi: 1) pembuat kekacauan di seantero kekaisaran (17:6); dan 2) menentang Kaisar dengan menganggap Yesus sebagai Raja (17:7). Untuk yang kedua, tentu ini merupakan sebuah tuduhan yang besar, yang secara legal bisa menjadi alasan bagi pemerintah untuk menghukum Paulus. Salah satu latar belakang yang kemungkinan muncul di sini adalah ketetapan terkait dengan pelarangan terhadap upaya penggantian pemimpin

dengan Esler dan Cassidy, Alexander memahami bahwa kisah pengadilan yang dihadapi Paulus dalam Kisah Para Rasul mencerminkan pemikiran politik dari Lukas.

${ }^{16}$ Esler, Community and Gospel in Luke-Acts, 201-202.

${ }^{17}$ Dalam kisah di Tesalonika yang tercatat pada Kisah Para Rasul 17:1-9 memang tidak diceritakan interaksi langsung antara Paulus dengan pembesar-pembesar. Namun, nas ini memperlihatkan respons para pemimpin kota terhadap tuduhan yang ditujukan kepada Paulus, sehingga menjadi relevan bagi tujuan dari tulisan ini. 
melalui tindakan makar. ${ }^{18}$ Tentu dengan memberitakan Yesus sebagai Raja, secara politis, Paulus bisa dituding sebagai orang yang subversif. ${ }^{19}$

Keadaan ini kemudian menggelisahkan para pembesar kota. Namun menariknya, naratif ini seolah-olah menggambarkan para pembesar tidak melihat aktivitas Paulus sebagai ancaman bagi keamanan wilayah mereka. Pernyataan, "Tetapi setelah mereka [para pembesar kota] mendapat jaminan dari Yason dan dari saudara-saudara lain, mereka pun dilepaskan" (17:9), mengindikasikan hal tersebut. Tidak ada upaya dari petinggi-petinggi Romawi tersebut untuk menangkap Paulus. Jaminan dari Yason sudah cukup, yaitu jaminan yang memberi kepastian bahwa Paulus tidak akan menimbulkan kekacauan di Tesalonika.

Terlihat bahwa tuduhan menimbulkan kekisruhan dan menentang kedaulatan kaisar tidaklah terbukti. Bahkan petinggi-petinggi Tesalonika merasa tidak dibutuhkannya tindakan hukum yang lebih lanjut. Terkait dengan tujuan dari studi tulisan ini, maka citra kekristenan yang bukanlah oposisi terhadap negara terlihat di sini. Pihak yang menekan Kekristenan dalam konteks ini bukanlah pihak Romawi, melainkan kaum Yahudi.

Ide tersebut ditegaskan oleh dua naratif yang mengantarai kisah di Tesalonika (Kis. 17:1-9) dan kisah di hadapan Galio (Kis. 18:11-17), yaitu kisah di Berea (Kis. 17:10-15) dan Atena (Kis. 17:16-34). Karena kekisruhan yang terjadi di Tesalonika, Paulus diminta oleh saudarasaudara di sana untuk segera pergi ke Berea (Kis. 17:10). Kisah di Berea sangat erat hubungannya dengan Kisah di Tesalonika. ${ }^{20}$ Sama halnya dengan di Tesalonika, di Berea pun Paulus pergi ke rumah ibadah Yahudi (Kis. 17:10) dan banyak dari kalangan Yahudi dan Yunani menjadi percaya (Kis. 17:12). Selain itu, pertentangan yang dihadapi di Berea adalah dari komunitas Yahudi yang sama, yaitu mereka yang berasal dari Tesalonika (Kis. 17:13). Oleh sebab itu, akhirnya Paulus meninggalkan Berea menuju Atena. Dari kisah ini jelas bahwa bukan pemerintahan Romawi yang berdiri sebagai oposisi, melainkan komunitas Yahudi yang menolak Paulus.

${ }^{18}$ Beberapa ahli Perjanjian Baru mengaitkan ini dengan peraturan yang dikeluarkan oleh kekaisaran Romawi yang menetapkan dilarangnya tindakan-tindakan yang bertujuan menjatuhkan kedaulatan kaisar. Lihat Charles Kingsley Barrett, Acts 1528, The international critical commentary (London: T \& T Clark, 2004), 816; I Howard Marshall, Acts, Tyndale New Tetstament Commentaries (Downers Grove: InterVarsity, 2008), 295-296; Ben Witherington, The Acts of the Apostles: A Socio-Rhetorical Commentary (Grand Rapids: Eerdmans, 1998), 508.

${ }^{19}$ Witherington, The Acts of the Apostles, 508.

${ }^{20}$ Robert C. Tannehill, The Narrative Unity of Luke-Acts: A Literary Interpretation: The Acts of the Apostles, vol. 2 (Minneapolis: Fortress Press, 1994), 207. 
Dalam kisah di Atena, tidak dijumpai persinggungan dengan komunitas Yahudi. Menariknya, penolakan keras sebagaimana yang terjadi di Tesalonika dan Berea tidak muncul. Memang ada orang-orang Yunani di Areopagus yang menolak ajaran Paulus (Kis. 17:32), namun itu tidak berpotensi penganiayaan atau penangkapan. Jadi semakin jelas bahwa keberadaan orang-orang Yahudilah yang memunculkan risiko penangkapan Paulus oleh pihak Romawi.

Secara politis, Paulus tidak dianggap sebagai ancaman oleh pihak Romawi. Kisah lain yang mencerminkan sensitivitas politik Lukas adalah sikap Galio ketika Paulus melakukan pelayanan di Korintus (Kis. 18:11-17). Bahkan Galio memandang bahwa Paulus tidak melakukan kejahatan yang bertentangan dengan hukum yang berlaku. Kalaupun terjadi kekrisuhan, itu bukanlah terkait dengan hal politis melainkan teologis, yang menurutnya bisa diselesaikan di antara sesama Yahudi.

Dalam Kisah Para Rasul 18:1l, dilaporkan bahwa setelah Paulus mendengar peneguhan dari suara Tuhan untuk tetap bertahan di Korintus (Kis. 18:9-10), dia menetap di kota tersebut selama satu tahun enam bulan. Lalu dikatakan setelah Galio menjadi gubernur, orang-orang Yahudi berupaya untuk membawa Paulus ke pengadilan dengan tuduhan bahwa dia telah membujuk orang-orang untuk menyembah Allah yang berbeda dengan hukum (18:13). Melihat respons Galio, mungkin sekali bahwa yang dimaksud dengan hukum di sini adalah hukum keagamaan Yahudi. Kemungkinan landasan bagi orang-orang Yahudi berharap Galio campur tangan adalah terkait dengan upaya menjaga ketenangan kota, sehingga Paulus mendapat hukuman. ${ }^{21}$

Namun, apa yang diharapkan orang-orang Yahudi tidak terjadi. Berdasarkan ucapannya dalam Kisah Para Rasul 18:14, 15, terlihat bahwa Galio tidak melihat adanya unsur pelanggaran hukum Romawi dalam tindakan Paulus yang dilaporkan oleh orang-orang Yahudi. Galio lebih melihat masalah yang terjadi terkait dengan unsur-unsur tertentu dalam agama Yahudi, yang kemudian membuat dia menolak menangani laporan orang-orang Yahudi tersebut. Melihat apa yang terjadi dalam naratif di hadapan Galio ini, Esler menjelaskan bahwa upaya orang-orang Yahudi, sejak kasus yang dihadapi Yesus, mengemas sedemikian rupa pertentangan-pertentangan keagamaan menjadi sejajar dengan hal-hal politis atau hukum kekaisaran adalah hal yang banyak diulang dalam tulisan Lukas. ${ }^{22} \mathrm{Hal}$ ini akan terus terlihat ketika Paulus diperhadapkan kepada petinggi-petinggi Romawi lainnya.

Melalui bagian ini kembali Paulus tidak dilihat oleh aparat Romawi sebagai ancaman terhadap stabilitas kekaisaran. Pandangan

${ }^{21}$ Witherington, The Acts of the Apostles, 552.

${ }^{22}$ Esler, Community and Gospel in Luke-Acts, 204. 
Galio terhadap kasus Paulus memunculkan gagasan bahwa aksi dan ajaran Paulus tidak menyerang hukum negara. Jadi sekali lagi, sama halnya dengan apa yang ditampilkan dalam kisah di Tesalonika, Kekristenan digambarkan tidak sebagai oposisi kekaisaran Romawi.

\section{Paulus di Hadapan Feliks (Kis. 24:1-27)}

Bagian lain yang penting terkait dengan tujuan dari tulisan ini adalah naratif Paulus berhadapan dengan Felix. Dalam kisah peradilan ini, diperlihatkan tuduhan kepada Paulus dan pembelaan dirinya. Di bagian akhir dicatatkan respons Felix yang juga tidak menemukan indikasi Paulus melanggar hukum negara. Dari sudut pandang konteks logika, kisah Paulus di hadapan Feliks dapat dikelompokkan ke dalam bagian teks yang lebih besar, yaitu Kis. 23:11-26:32, yang secara keseluruhan mendeklarasikan ketidakbersalahan Paulus di hadapan para penguasa. ${ }^{23}$ Dalam konteks ini pernyataan-pernyataan yang secara eksplisit menyatakan bahwa Paulus tidak bersalah dalam pandangan para penguasa adalah Kis. 23:29; 25:25; 26:31, 32.

Bagaimana Paulus sampai ke hadapan Feliks? Semuanya bermula dari Kisah Para Rasul 21:37-36, dimana dicatatkan bahwa Paulus ketika berada di Bait Allah di Yerusalem ditangkap dan coba untuk dibunuh oleh orang-orang Yahudi. Sebelum dibunuh Paulus dibawa oleh prajurit Romawi yang bertugas mengamankan keadaan (Kis. 21:31-36). Namun orang-orang Yahudi tetap berupaya membunuh Paulus (Kis. 23:12-22). Persekongkolan untuk membunuh Paulus kemudian membuat kepala pasukan Romawi berkeputusan mengirim Paulus ke Kaisarea menghadap Feliks (Kis. 23:23-35).

Dalam Kisah Para Rasul 23:23-35, tercatat bahwa sebelum dikirim ke Kaisarea, Klaudius Lisias, sang kepala pasukan, mengirim surat kepada Felix terkait dengan latar belakang kasus Paulus dan kenapa dia dikirim ke Kaisarea untuk menghadap Felix. Isi surat Klaudius bisa dilihat sebagai transisi dalam perkembangan plot cerita yang menjaga ide ketidakbersalahan Paulus dari sudut pandang hukum Romawi. Pernyataan Klaudius kepada Feliks mengulang kembali pandangan Galio bahwa masalah terkait dengan Paulus adalah kasus perbedaan keyakinan teologis, bukan pelanggaran hukum Romawi. Penjelasan Klaudius, terkait kasus Paulus, mengatakan:

Untuk mengetahui apa alasannya mereka [orang-orang Yahudi] mendakwa dia [Paulus], aku menghadapkannya ke Mahkamah Agama

${ }^{23}$ Charles H. Talbert, Reading Acts: A Literary and Theological Commentary on the Acts of the Apostles, Rev. ed., Reading the New Testament (Macon, Ga: Smyth \& Helwys Pub, 2005), 197. 
mereka. Ternyata bagiku, bahwa ia didakwa karena soal-soal hukum Taurat mereka, tetapi tidak ada tuduhan, atas mana ia patut dihukum mati atau dipenjarakan. ${ }^{24}$ Kepadaku telah diberitahukan, bahwa ada komplotan merencanakan membunuh dia. Karena itu aku segera menyuruh membawa dia kepadamu [Feliks], sedang kepada para pendakwa telah kuberitahukan, bahwa mereka harus mengajukan perkara itu kepadamu (Kis. 23:28-30).

Lukas ingin memberi kejelasan kepada pembacanya bahwa Paulus bukanlah seorang kriminal yang bisa mengancam kekaisaran. Jelas dari pernyataan Klaudius di atas, bahwa tidak ada dasar untuk menghukum Paulus baik dengan pemenjaraan maupun hukuman mati. Dalam kaca mata pemerintahan Romawi, masalah yang menjerat Paulus adalah hal keagamaan yang mengundang kemarahan orang-orang Yahudi. Bagi Klaudius, ini adalah urusan internal agama Yahudi, kekaisaran seharusnya tidak mencampurinya. Ini sama halnya dengan pemahaman Galio dalam melihat kasus Paulus di Korintus.

Mengapa kasus Paulus harus diteruskan kepada Feliks? Berdasarkan pernyataan Klaudius bahwa permufakatan orang-orang Yahudi yang hendak membunuh Pauluslah yang menyebabkan dia dikirim kepada Feliks. ${ }^{25}$ Kasus Paulus yang dibawa kepada Feliks tidak didasarkan pada kebersalahan atau berupaya menegaskan kesalahan Paulus, melainkan situasi yang tidak kondusif terkait dengan rencana orang Yahudi untuk membunuh Paulus. Naratif ini secara jelas mengatakan bahwa dari sudut pandang hukum Romawi, petinggi-petinggi Romawi tidak melihat pelanggaran yang pantas membuat Paulus dijatuhi hukuman.

Paulus diizinkan menyampaikan pembelaannya yang menegaskan bahwa Paulus tidak pernah bermaksud menimbulkan huru-hara (Kis. 24:11-13). Sekalipun mengabdi kepada Allah melalui Jalan Tuhan, yang dianggap oleh tua-tua Israel sebagai sebagai sekte (lih. Kis. 24:5), Paulus tetap mempercayai kitab Taurat dan kitab nabi-nabi. Di samping itu, secara etis, Paulus pun menunjukkan dirinya sebagai orang yang tetap berusaha memelihara sikap hidup baik. Hal tersebut terbukti pada kedatangannya ke Yerusalem untuk membawa bantuan buat saudarasuadara di sana dan juga memberi persembahan (Kis. 24:17). Berdasarkan hal tersebut Paulus menegaskan bahwa tidak ada alasan bagi orangorang Yahudi menangkapnya. Menurutnya, penangkapannya lebih dikarenakan keyakinan yang dimiliki Paulus berkaitan dengan kebangkitan (24:21).

Sekalipun Feliks tidak membebaskan Paulus, bukan berarti dia menganggap Paulus telah bersalah. Ungkapan, "Tetapi Feliks yang tahu

${ }^{24}$ Cetak miring oleh penulis untuk memberi penekanan.

${ }^{25}$ Lihat latar belakang dalam Kisah Para Rasul 23:12-22. 
benar-benar akan Jalan Tuhan, menangguhkan perkara mereka ..." (24:22), menandakan bahwa bagi Feliks, sebagai perwakilan pemerintahan Romawi, Jalan Tuhan bukanlah sebuah pelanggaran. Secara tidak langsung, sikap Feliks mengindikasikan tidak ditemukannya bukti kuat untuk menghukum Paulus. Keringanan yang diberikan dengan memberikan tahanan ringan dan kebebasan untuk dijenguk menunjukkan hal tersebut. Ditambah, dengan informasi pemenjaraan Paulus yang dilakukan oleh pengganti Feliks, yaitu Perkius Festus, dilakukan dengan alasan mengambil hati orang Yahudi, maka semakin ditegaskan ketidakbersalahan Paulus (24:27).

Bila pembacaan diteruskan maka akan dijumpai lagi interaksi lainnya antara Paulus dan pemimpin Romawi lainnya. Namun tulisan ini tidak akan membahas kisah-kisah tersebut, karena kesimpulannya akan sama seperti apa yang disajikan dalam kisah di Tesalonika, Korintus dan ketika berhadapan dengan Feliks. Kesemuanya menunjukkan kepada pembaca bahwa Paulus bukanlah seorang kriminal yang tidak mengindahkan hukum-hukum kekaisaran. ${ }^{26}$

Sebagai kesimpulan untuk analisis terhadap nas-nas di atas adalah Kekristenan hadir bukan sebagai ancaman bagi pemerintahan Romawi. Terkait bagian-bagian yang memunculkan motif politik Lukas, Esler mengatakan:

The general impression communicated by this politically sensitive material is that Jesus and his followers did not contravene Roman law and were therefore not a threat to the empire, even though Jewish authorities repeatedly initiated proceedings designed to prove the opposite and occasionally enjoyed some success before Roman officials whose weakness or self-seeking prevented the judicial system they administered from operating effectively. ${ }^{27}$

Kekristenan bukanlah musuh negara. Dalam sudut pandang kesatuan dan keutuhan naratif, tulisan ini mengaitkan fakta tersebut dengan cara hidup jemaat perdana yang dilaporkan Lukas dalam Kisah Para Rasul 2:44-45;4:33-35, termasuk dengan kisah penangkapan Paulus di Yerusalem: kedatangannya ke Yerusalem, selain memberi persembahan, dia juga membawa bantuan kepada saudara-saudara di sana (24:17; band. 1 Kor. 16:1-4; Rom. 15:25).

Gagasannya adalah sebagai rekan negara, umat Kristen juga terpanggil-bahkan bisa dikatakan secara teologis terpanggil-untuk menunjukkan kepedulian sosial mereka. Tujuannya adalah mewujudkan

${ }^{26}$ Lihat Esler, Community and Gospel in Luke-Acts, 201-205.

${ }^{27}$ Ibid., 204-205. 
apa yang tertulis dalam Kisah Para Rasul 4:34: "Sebab tidak ada seorangpun yang berkekurangan di antara mereka ...." Maka gereja harus mampu menghadirkan shalom di tengah-tengah masyarakat, sebagai wujud dukungan kepada negara yang terpanggil untuk menyejahterakan warganya. Bukankah ini sesuai dengan rancangan global Allah yang ditunjukkan oleh Lukas dalam Injilnya: "Ia [Allah] melimpahkan segala yang baik kepada orang yang lapar ..." (Luk. 1:53).28 Maka secara teologis, umat Allah memiliki tanggung jawab sosial dalam mewujudkan kepedulian Allah terhadap mereka yang secara sosial lemah. Gereja harus mampu menghadirkan pelayanan non-dulistik, ${ }^{29}$ yaitu bentuk pelayanan yang memperhatikan seluruh kebutuhan manusia. Dengan keyakinan teologis inilah, gereja bisa menjadi umat Allah, sekaligus rekan negara dalam mewujudkan kesejahteraan.

\section{Catatan Sejarah Abad Kedua: Kepedulian Gereja}

Sebagaimana yang telah disampaikan di atas, sikap "politis" Kekristenan dalam Kisah Para Rasul, dalam kaca mata kesatuan naratif, tidak bisa dipisahkan dengan perhatian gereja terhadap isu-isu sosial. Perpaduan antara kepedulian sosial dan tidak adanya sikap permusuhan terhadap Romawi terwujud dalam sejarah awal Kekristenan. Ada catatan-catatan penting yang berasal dari abad kedua yang menggambarkan bahwa gereja terlibat aktif dalam membangun kota mereka. Bahkan, dalam analisisnya terhadap kemunculan gereja, Rodney Stark menyebut gereja sebagai pembawa revitalisasi..$^{30}$

Catatan pertama yang menarik adalah tulisan kepada Diognetus, Epistle of Mathetes to Diognetus. ${ }^{31}$ Tulisan ini diperkirakan dibuat di sekitar penghujung abad kedua, dengan penulis yang tidak diketahui-penulis

\footnotetext{
${ }^{28}$ Lukas 1:53, yang adalah bagian dari nyanyian Maria dalam meresponi kedatangan Sang Mesias, dianggap sebagai salah satu kerangka teologis dalam mengembangkan karakteristik pelayanan Yesus dalam Injil Lukas. Yesus yang digambarkan sebagai Sang Mesias yang memiliki kepedulian terhadap mereka yang tertindas (Luk. 4:16-30), merupakan bagian dari karya Allah yang memiliki kepedulian terhadap mereka yang secara sosial lemah.

${ }^{29}$ Pelayanan dualistik cenderung memisahkan manusia menjadi dua unsur, yaitu unsur rohani dan badani. Kemudian yang menjadi perhatian dalam pelayanan ini adalah sisi rohani manusia. Terkesan, kebutuhan-kebutuhan yang terkait keberadaan manusia secara fisik dianggap sebagai hal sekunder.

${ }^{30}$ Rodney Stark, The Rise of Christianity: How the Obscure, Marginal Jesus Movement Became the Dominant Religious Force in the Western World in a Few Centuries (San Francisco.: HarperSanFrancisco, 1997).

${ }^{31}$ Diambil dari J. B. Lightfoot, trans., "The Epistle of Mathetes to Diognetus,"

Early Christian Writing, accessed September 20, 2017,

http://www.earlychristianwritings.com/text/diognetus-lightfoot.html.
} 
hanya menyebut dirinya sebagai Mathetes ('murid'). ${ }^{32}$ Pada bab 5 dari tulisan tersebut disampaikan hal-hal yang berkenaan dengan sikap hidup orang-orang Kristen pada masa itu. Secara umum dalam bagian tersebut dituliskan bahwa orang-orang Kristen memiliki sikap hidup yang baik di dalam masyarakat, sekalipun anggota masyarakat belum tentu memperlakukan mereka dengan baik. Terkait dengan sikap terhadap hukum negara dan dengan sesama, disampaikan bahwa umat Kristen adalah orang-orang yang taat hukum dan mengasihi semua orang, sekalipun semua orang menganiaya mereka (Diognetus 5:10-11).

Catatan abad kedua lainnya yang menggambarkan karakteristik hidup jemaat awal adalah Apology, karya dari Tertullian. Dalam tulisan tersebut digambarkan bahwa komunitas Kristen memiliki kebiasaan mengumpulkan dana secara suka rela (Apology 58). Lebih jauh dijelaskan bahwa dana yang terkumpul digunakan untuk mendukung mereka yang membutuhkan, seperti orang miskin dan anak yatim piatu:

For they [dana] are not taken thence and spent on feasts, and drinkingbouts, and eating-houses, but to support and bury poor people, to supply the wants of boys and girls destitute of means and parents, and of old persons confined now to the house; such, too, as have suffered shipwreck; and if there happen to be any in the mines, or banished to the islands, or shut up in the prisons, for nothing but their fidelity to the cause of God's Church, they become the nurslings of their confession (Apology 39). ${ }^{33}$

Dua catatan dari abad kedua di atas memberikan gambaran bahwa aksi dalam mendukung mereka yang berkesusahan merupakan karakteristik penting dalam jemaat pada masa itu. Ini selaras dengan temuan dari Stark yang memaparkan bahwa umat Kristen di masa awal perkembangannya adalah pembawa revitalisasi. Dalam fungsinya sebagai pembawa restorasi bagi kota-kota rusak, Kekristenan memperlihatkan kepedulian sosial yang cukup memberi solusi bagi permasalahan yang ada dalam sebuah kota. Misalnya, membantu orang-orang asing, anakanak yatim piatu, janda-janda dan korban bencana alam. ${ }^{34}$

Setidaknya sampai pada zaman dituliskannya catatan kuno, seperti tulisan Tertullian dan surat kepada Diognetus, aksi sosial menolong mereka yang berkekurangan adalah karakter penting

${ }^{32}$ Robert M. Grant, "Diognetus, Epistle To," in The Anchor Bible Dictionary, ed. David Noel Freedman, vol. 2 (New York: Doubleday, 1992), 202.

${ }^{33}$ Tertullian, "The Apology," trans. Roberts-Donaldson, Early Christian Writing, accessed September 20, 2017,

http://www.earlychristianwritings.com/text/tertullian0l.html.

${ }^{34}$ Stark, The Rise of Christianity, 161. 
pelayanan Kristen. Terlihat bahwa tidak ada dualisme yang memisahkan kebutuhan spiritual dan fisik. Pemulihan yang dibawa oleh pelayanan tersebut merupakan pemulihan menyeluruh. Ini merupakan fondasi penting dalam melihat hubungan antara umat Kristen dan negara. Gereja harus mampu menghadirkan diri sebagai bagian dari masyarakat yang mampu menjadi rekan negara untuk menghadirkan kesejahteraan.

\section{Gereja Indonesia Sebagai Rekan Negara}

Gereja memiliki tanggung jawab sosial untuk menghadirkan shalom sebagai bagian dari panggilannya. Pertanyaannya adalah, pemikiran apa yang bisa dimunculkan bagi konteks di Indonesia. Pada bagian ini, tulisan ini akan mencoba menyampaikan gagasan yang dapat dipertimbangkan bagi pelaku pelayanan Kristen di negeri ini, khususnya terkait dengan upaya meresponi bentuk-bentuk isu sosial. Berbicara tentang isu-isu sosial tentu ada banyak yang bisa didaftarakan, namun tulisan ini akan fokus pada isu kemiskinan.

Gereja memiliki tanggung jawab sebagai umat Allah dan warga negara untuk membantu negara mendukung mereka yang secara ekonomi lemah, agar mereka dapat meningkatkan taraf hidup. Berdasarkan data Badan Pusat Statistik Indonesia sampai dengan Maret 2018, angka kemiskinan di Indonesia berkisar 9,82\%. ${ }^{35}$ Bila diperhatikan persentase per provinsi maka akan dijumpai daerah di Indonesia Timur yang mayorit penganuat agama Kristen tergolong besar persentase kemiskinannya: Papua Barat, penduduk Kristen 53,76\%; Papua, penduduk Kristen 65,36\%; dan Nusa Tenggara Timur, penduduk Kristen $34,72 \%$ dan Katolik 54,1\%. ${ }^{36}$ Adapun persentase kemiskinan di daerahdaerah tersebut sampai dengan Maret 2018: Papua Barat 23,01\%; Papua

${ }^{35}$ Badan Pusat Statistik, "Persentase Penduduk Miskin Menurut Provinsi $2007-$ 2018," diakses 24 Juli 2018,

https:/www.bps.go.id/dynamictable/2016/08/18/1219/persentase-penduduk-miskinmenurut-provinsi-2007---2018.html.

${ }^{36}$ Berdasarkan data dari Kementrian Agama didapati bahwa jumlah penduduk Kristen di Papua Barat adalah 408.841 jiwa dari total 760.422 jiwa; Papua 1.855.245 jiwa dari total 2.833.381 Jiwa; dan Nusa Tenggara Timur warga Kristen berjumlah 1.627.157, dan Katolik 2.535.937 jiwa dari total 4.683.827 jiwa (Kementrian Agama RI, Kementrian Agama Dalam Angka 2016 (Jakarta: Biro Hubungan Masyarakat, Data dan Informasi Sekretariat Jenderal Kementerian Agama, 2017), 49, diakses 25 Juli 2018, https://kemenag.go.id/myadmin/public/data/files/users/3/KEMENAG\%20DALAM\%20 ANGKA\%202016---OK\%20(1).pdf); Bandingkan dengan persentase penduduk berdasarkan agama oleh Badan Pusat Statistik hasil dari sensus 2010 (Badan Pusat Statistik, "Sensus Penduduk 2010: Penduduk Menurut Wilayah dan Agama yang Dianut," http://sp2010.bps.go.id/index.php/site/tabel?tid=321\&ewid=0000000000). 
27,74\%; dan Nusa Tenggara Timur 21,35\%.37 Angka ini tinggi bila dibandingkan dengan provinsi yang lainnya. Berdasarkan angka-angka di atas, gereja di Indonesia memiliki tanggung jawab untuk terlibat aktif dalam menolong mereka yang bergelut dengan kemiskinan.

Apa yang bisa dilakukan oleh gereja? Tulisan ini mencoba menyodorkan sebuah masukan yang bisa dilakukan umat Kristen untuk menghadirkan transformasi bagi masyarakat. Sebagai komunitas yang dipanggil sebagai pewarta Kerajaan Allah, gereja perlu menguatkan pelayanan diakonia. Tentu semua gereja, atau setidaknya mayoritas gereja, memiliki pelayanan diakonia. Namun pertanyaannya adalah, sampai sejauh mana pelayanan tersebut dimaksimalkan untuk membangun kehidupan umat secara utuh.

Pelayanan diakonia harus dipandang sebagai panggilan gereja, bukan hanya perbuatan amal yang dilakukan oleh orang-orang Kristen. Dalam tinjauannya, Siswanto menjelaskan bahwa pelayanan diakonia merupakan bagian penting dalam pelayanan atau misi gereja. Pelayanan diakonia adalah perwujudan identitas umat Allah. Sekaligus perwujudan kesadaran akan natur pelayanan Yesus Kristus:

... [Pelayanan diakonia] merupakan ungkapan jati diri Gereja yang dipanggil menjadi tanda-tanda pertolongan dan keselamatan bagi dunia. Sehingga Gereja melalui pelayanannya menjadi kesaksian atas kasih-Nya terhadap yang miskin dan yang menderita. Oleh karena itu diakonia yang hidup dan sadar merupakan hasil kepercayaan kepada Yesus yang hadir di dunia sebagai seorang pelayan (Luk. 22:27). ${ }^{38}$

Dengan demikian pelayanan diakonia memiliki tempat yang penting dalam karya gereja. Bahkan tidak kalah penting dengan aksi pemberitaan Firman. Dalam kaitan dengan naratif pemilihan tujuh pelayan meja (Kis. 6:1-7) dalam tulisannya, Jozef M. N. Hehanussa melihat bahwa pelayanan diakonia dan pemberitaan Firman memiliki arti penting yang seimbang. Keduanya mewartakan Kerajaan Allah:

Pelayanan diakonia gereja ini merupakan satu kesatuan dengan pelayanan Firman. Keduanya memiliki arti yang sama penting dan keduanya saling berkaitan satu dengan yang lain. Keduanya merupakan perwujudan 'Kerajaan Allah' dalam kehidupan manusia. Yang satu, pelayanan Firman,

\footnotetext{
${ }^{37}$ Badan Pusat Statistik, "Persentase Penduduk Miskin Menurut Provinsi 2007 2018."

${ }^{38}$ Krido Siswanto, "Tinjauan Teoritis Dan Teologis Terhadap Diakonia Transformatif Gereja," Jurnal Simpson 1, no. 1 (2016): 104.
} 
dalam bentuk kata-kata atau verbal, sedangkan yang lain, pelayanan diakonia, dalam bentuk praxis atau karya atau tindakan. ${ }^{39}$

Berdasarkan penjelasan di atas, pelayanan diakonia bukanlah sekedar pelengkap bagi karya gereja. Apa yang terlihat di bagian ini tentang pentingnya pelayanan diakonia, sudah terjelaskan di bagian sebelumnya dimana diulas dimensi sosial dari tulisan Lukas. Injil Lukas, melalui pelayanan Yesus, yang diteruskan oleh Kisah Para Rasul, melalui pelayanan para rasul, menunjukkan bahwa kepedulian terhadap kelemahan sosial dan fisik manusia adalah bagian penting dalam misi gereja.

Maka gereja, sebagai umat Allah, dan rekan negara, harus menerapkan pelayanan diakonia yang bersifat transformatif. Secara teologis, pelayanan tersebut harus didasarkan pada karya Allah yang mempedulikan seluruh keberadaan manusia: roh dan fisik. Di samping itu, harus dilakukan dalam konteks karya penebusan yang bersifat holistik: penebusan yang memulihkan seluruh aspek hidup manusia. Sebagai bagian dari kesaksian gereja, pelayanan tersebut juga harus membawa kasih dan berkat Allah bagi anggota masyarakat lainnya, yang berada di luar gereja.

Gereja bukan hanya sekadar menjadi pusat kegiatan ritualistik, namun sebagai bagian masyarakat, harus mampu mengaktualkan diri sebagai pembawa transformasi. Sebagaimana dijelaskan oleh Zakaria J. Ngelow:

Gereja bukan sekadar lembaga ritual keagamaan, melainkan alat yang dihadirkan Tuhan di dalam dunia untuk kesaksian Injil Kerajaan Allah mengenai kasih, keadilan dan damai sejahtera Allah dalam Kristus. Karena itu gereja terpanggil untuk melakukan transformasi kehidupan manusia pribadi maupun masyarakat. ${ }^{40}$

Dengan pola karya yang demikian, pelayanan Kristen tidak dipahami secara dualistik, melainkan holistik. Melalui prinsip seperti inilah gereja mampu hadir sebagai rekan negara untuk menghadirkan damai sejahtera bagi masyarakat.

Karya misi yang holistik inilah yang telah diperlihatkan Allah sejak dalam Perjanjian Lama. Dalam analisisnya Christopher Wright menjelaskan, dengan bertolak dari gagasan teologis yang ada pada tradisi

${ }^{39}$ Jozef MN Hehanussa, "Pelayanan Diakonia Yang Transformatif: Tuntutan Atau Tantangan," Gema Teologi 36, no. 1 (2013): 129.

${ }^{40}$ Zakaria J. Ngelow, "Turut Membina Indonesia Sebagai Rumah Bersama Peran Gereja Dalam Politik Di Indonesia,” Jurnal Jaffray 12, no. 2 (2014): 223. 
jubilee dalam masyarakat Israel, bahwa misi penginjilan Kristen memiliki dimensi sosial:

Now of course I am not suggesting that the jubilee was 'evangelistic' in any contemporary sense. What I do mean is that the fundamental theology behind it also lies behind our practice of evangelism. The assumptions are the same. The theological underpinning of the socio-economic legislation of the jubilee is identical to that which undergirds the proclamation of the kingdom of God. It is no wonder, as we shall see in a moment, that the jubilee itself became a picture of the new age of salvation that the New Testament announces. It is an institution that models in a small comer of ancient Israelite economics the essential contours of God's wider mission for the restoration of humanity and creation. ${ }^{41}$

Uraian Wright ini menegaskan bahwa secara teologis gereja memiliki tanggung jawab sosial dalam panggilan misinya. Ini semakin dipertegas dengan kenyataan bahwa warga gereja juga adalah bagian negara, yang seharusnya mampu memberi kontribusi bagi pengembangan masyarakat. Salah satu alat yang bisa digunakan gereja dalam konteks Indonesia adalah memperkuat pelayanan diakonia yang bersifat transformatif sebagai bagian misi gereja.

\section{Kesimpulan}

Injil Lukas, melalui Kisah Para Rasul, menunjukkan tidak ada permusuhan antara gereja dan pemerintah Romawi. Dalam tulisan ini, kenyataan tersebut dipahami bahwa gereja, sebagai umat Allah, harus bisa menempatkan diri sebagai rekan negara dalam mewujudkan shalom di tengah-tengah masyarakat. Bacaan terhadap Kisah Para Rasul, khususnya bagian-bagian yang menghadirkan interaksi antara Paulus dan penguasa-penguasa Romawi, melalui pendekatan analisis naratif yang mengedepankan kesatuan teks, maka gereja memiliki tanggung jawab sosial membantu negara mewujudkan kesejahteraan. Karena itu, gereja di Indonesia harus mampu memaksimalkan pelayanan diakonia, bukan hanya sebagai kegiatan amal gereja, melainkan sebagai unsur penting pelayanan Kristen untuk menghadirkan transformasi bagi warga gereja dan masyarakat yang lebih luas.

\section{Kepustakaan}

${ }^{41}$ Christopher J. H. Wright, "Theology of Jubilee: Biblical, Social and Ethical Perspectives," Evangelical Review of Theology 41, no. 1 (January 2017): 15. 
Alexander, Loveday. "Luke's Political Vision." Interpretation 66, no. 3 (July 2012): 283-293. https://doi.org/10.1177/0020964312443184.

Badan Pusat Statistik. "Persentase Penduduk Miskin Menurut Provinsi 2007-2018." Diakses 242018.

https://www.bps.go.id/dynamictable/2016/08/18/1219/persentasependuduk-miskin-menurut-provinsi-2007---2018.html.

. "Sensus Penduduk 2010: Penduduk Menurut Wilayah dan Agama yang Dianut." Diakses 24 Juli 2018.

http://sp2010.bps.go.id/index.php/site/tabel?tid=321\&wid=000000 0000.

Barrett, Charles Kingsley. Acts 15-28. The international critical commentary. London: T \& T Clark, 2004.

Blomberg, Craig L. Neither Poverty nor Riches: A Biblical Theology of Material Possession. Grand Rapids: Eerdmans, 1999.

Bock, Darrell L. A Theology of Luke-Acts: God's Promised Program, Realized for All Nations. Biblical Theology of the New Testament. Grand Rapids: Zondervan, 2012.

Cadbury, Henry J. The Making of Luke-Acts. Peabody: Hendrickson Publishers, 1999.

Cassidy, Richard J. Jesus, Politics, and Society: A Study of Luke's Gospel. Wipf and Stock Publishers, 2015.

Esler, Philip Francis. Community and Gospel in Luke-Acts: The Social and Political Motivations of Lucan Theology. Cambridge: Cambridge University, 1989.

Grant, Robert M. "Diognetus, Epistle To." In The Anchor Bible Dictionary, edited by David Noel Freedman, 2:201. New York: Doubleday, 1992.

Green, Joel B. "Luke, Gospel Of." In Dictionary of Jesus and the Gospels, edited by Joel B Green, 540-52. Second Edition. Downers Grove: IVP Academic, 2013.

Harris, Ben. "l Gospel, 4 Acts: Introduction (s) to the Genuis of Luke." Evangelical Quarterly 89, no. 1 (January 2018): 3-20.

Hehanussa, Jozef MN. "Pelayanan Diakonia Yang Transformatif: Tuntutan Atau Tantangan.” Gema Teologi 36, no. 1 (2013): 127-138.

Helweldery, Ronald. "Gereja dalam Konteks Relasi Negara dan Masyarakat (Sebuah Upaya Memahami Reposisi Peran Politis Gereja)." Waskita: Jurnal Studi Agama dan Masyarakat 2, no. 2 (2014): 123-145.

Kementerian Agama RI. Kementerian Agama Dalam Angka 2016. Jakarta: Biro Hubungan Masyarakat, Data dan Informasi Sekretariat Jenderal Kementerian Agama, 2017. Diakses 25 Juli 2018. 
https://kemenag.go.id/myadmin/public/data/files/users/3/KEMEN AG\%20DALAM\%20ANGKA\%202016---OK\%20(1).pdf.

Kim, Sebastian C. H. "Mission's Public Engagement: The Conversation of Missiology and Public Theology." Missiology 45, no. 1 (2017): 7-24.

Kingsbury, Jack Dean. Matthew as Story. 2nd ed. Philadelphia: Fortress Press, 1988.

Kustini dan Syaiful Arif, "Kekristenan dan Nasionalisme di Kota Bogor" Harmoni: Jurnal Multikultural \& Multireligius 15, no. 2 (2016): 96-108 Lightfoot, J. B., trans. "The Epistle of Mathetes to Diognetus." Early Christian Writing. Diakses 20 September 2017.

http:/www.earlychristianwritings.com/text/diognetuslightfoot.html.

Marshall, I Howard. Acts. Tyndale New Tetstament Commentaries. Downers Grove: InterVarsity, 2008.

Marshall, I. Howard. "Acts and the "Former Treaties." In The Book of Acts in Its First Century Setting, edited by Bruce W. Winter and Andrew D. Clark, 1:163-182. Grand Rapids: Eerdmans, 1993.

Ngelow, Zakaria J. "Turut Membina Indonesia Sebagai Rumah Bersama Peran Gereja Dalam Politik Di Indonesia." Jurnal Jaffray 12, no. 2 (2014): 213-234.

Nihinlola, Emiola. "The Church as a Civil Society: An African Ecclesiology." Evangelical Review of Theology 41, no. 1 (January 2017): 48-56.

O'Toole, Robert F. "Luke's Position on Politics and Society in LukeActs." In Political Issues in Luke-Acts, edited by Richard J. Cassidy and Philip J. Scharper, 1-17. Eugene, OR: Wipf and Stock Publishers, 2015.

Resseguie, James L. Narrative Criticism of the New Testament: An Introduction. Grand Rapids: Baker Academic, 2015.

Roth, S. John. The Blind, the Lame, and the Poor: Character Types in Luke-Acts. Sheffield, England: Sheffield Academic Press, 1997.

Siswanto, Krido. "Tinjauan Teoritis Dan Teologis Terhadap Diakonia Transformatif Gereja." Jurnal Simpson 1, no. 1 (2016): 95-120.

Stark, Rodney. The Rise of Christianity: How the Obscure, Marginal Jesus Movement Became the Dominant Religious Force in the Western World in a Few Centuries. San Francisco.: HarperSanFrancisco, 1997.

Talbert, Charles H. Reading Acts: A Literary and Theological Commentary on the Acts of the Apostles. Rev. ed. Reading the New Testament. Macon, Ga: Smyth \& Helwys Pub, 2005. 
Tannehill, Robert C. The Narrative Unity of Luke-Acts: A Literary Interpretation. Vol. 1. 2 vols. Philadelphia: Fortress, 1986. . The Narrative Unity of Luke-Acts: A Literary Interpretation: The Acts of the Apostles. Vol. 2. Minneapolis: Fortress Press, 1994.

Tertullian. "The Apology." Translated by Roberts-Donaldson. Early Christian Writing. Diakses 20 September 2017. http://www.earlychristianwritings.com/text/tertullian0l.html.

Witherington, Ben. The Acts of the Apostles: A Socio-Rhetorical Commentary. Grand Rapids: Eerdmans, 1998.

Wright, Christopher J. H. "Theology of Jubilee: Biblical, Social and Ethical Perspectives." Evangelical Review of Theology 41, no. 1 (January 2017): 6-18. 